\title{
PENGEMBANGAN SISTEM INFORMASI PRODUKSI PADA PT. ALUMINA
}

\author{
Chandra $^{1}$, Orrick Oetomo ${ }^{2}$, Fandi Halim ${ }^{3}$ Sophya Hadini Marpaung ${ }^{4}$ \\ Jurusan Sistem Informasi STMIK Mikroskil, Medan, Inndonesia \\ Email: ${ }^{1}$ chandramn550@gmail.ac.id, ${ }^{2}$ orrick.oetomo@yahoo.com, ${ }^{3}$ fandi@mikroskil.ac.id, \\ ${ }^{4}$ sophya.marpaung@mikroskil.ac.id
}

\begin{abstract}
Abstrak
PT. Alumina adalah vendor penyedia jasa produksi aluminium seperti jendela, pintu, kaca dan sebagainya di kota Medan. Proses produksi cukup rumit dan rentan akan kesalahan sewaktu perhitungan bahan baku. Data pembuatan laporan harus dikumpulkan terlebih dahulu yang membutuhkan waktu cukup lama sehingga menghambat proses pembuatan laporan harga pokok penjualan (HPP) dan laporan berjalan. Sistem informasi produksi ini dapat menampilkan status pelaksanaan produksi yang berfungsi untuk mengetahui sejauh mana proses dari surat perintah kerja (SPK) sudah berjalan, perencanaan terhadap kebutuhan bahan baku, lama waktu yang dibutuhkan untuk produksi, penerimaan bahan baku untuk mengetahui bahwa produk siap untuk diproduksi, konfirmasi produksi bila produk yang sudah selesai, perhitungan harga pokok penjualan (HPP) serta laporan berjalan lainnya. Untuk mengat asi masalah yang dihadapi, penulis mengembangkan sistem informasi produksi menggunakan Microsoft Visual Basic 2012 untuk merancang tampilan dan aplikasi, Microsoft SQL Server 2012 untuk mengelolah database dan menggunakan Crystal Report 13.0.5 dalam pembuatan laporan-laporan. Penulis juga menggunakan metodologi SDLC (System Development Life Cycle) untuk pengembangan sistem informasi produksi sehingga permasalahan dapat diatasi
\end{abstract}

Kata kunci: sistem informasi, produksi,siklus produksi

\begin{abstract}
PT. Alumina is a company that provides aluminum production such as windows, doors, glass and so on in Medan city. Due to complexity and prone to errors when raw materials calculation and data for reports must be collected in advance which takes a long time so that hamper in preparing reports of cost of goods sold (HPP) and the current report. This product system information application can display the status of production process that serves to find out how far the process of work orders (SPK), material requirement planning, the length of time required for production, raw material receipt to know whether product is ready for production, production confirmation when the product is done, cost of goods sold (COGS) and other current reports. To solve the problems, writer has designed a production information systems using Microsoft Visual Basic 2012 to designing the visual and application, Microsoft SQL Server 2012 to manage the database and using Crystal Report 13.0.5 in the making of the reports. Writer also uses SDLC (System Development Life Cycle) method to help writer make a design for production information system applications so that the existing problems can be solved.
\end{abstract}

Keywords: information system, production, production cycle

\section{PENDAHULUAN}

PT. Alumina merupakan perusahaan yang menyediakan jasa produksi aluminium seperti jendela, pintu, kaca dan sebagainya di kota Medan. Proses bisnis jasa produksi di PT. Alumina dimulai dari adanya pemesanan oleh customer melalui divisi penjualan, lalu dilanjutkan dengan pemberian surat perintah kerja ke bagian produksi berdasarkan data berapa banyak yang akan diproduksi dengan ketentuan sesuai standar yang ditentukan.

Dalam menjalankan proses produksi tersebut, PT. Alumina terlebih dahulu membuat Surat Perintah Kerja (SPK), lalu dilakukan perhitungan bahan baku produksi secara manual, setelah melakukan perhitungan bahan baku maka divisi produksi akan mengelola persediaan, bila persediaan barang baku tidak mencukupi, divisi produksi akan melakukan permintaan barang baku ke divisi gudang. Setelah barang diterima divisi produksi akan menerima barang tersebut berdasarkan surat jalan yang sudah ada. Sewaktu produksi, bahan baku yang keluar dicatat secara manual melalui form pengunaan barang, lalu form tersebut akan di-input ke Microsoft Excel untuk mengetahui Harga Pokok Penjualan (HPP) produksi setelah produksi tersebut selesai. Setelah produksi selesai, divisi produksi akan mencatat jumlah barang jadi secara manual dan kemudian akan dikirim ke customer.

Di akhir bulan divisi produksi akan membuat laporan barang produksi, laporan Harga Pokok Penjualan (HPP), laporan pemakaian bahan baku, laporan produksi dan laporan upah. Kendala yang dihadapi adalah kurangnya keakuratan perhitungan bahan-bahan produksi yang diperlukan dan pembuatan laporan membutuhkan waktu yang lama dikarenakan penyusunan laporan akan dilakukan setelah semua proses produksi selesai, kemudian dilanjutkan dengan meng-input ke Microsoft Excel. Oleh karena itu, PT. Alumina membutuhkan sistem informasi produksi yang terkomputerisasi untuk membantu kinerja perusahaan seperti pengelolaan data, maupun pembuatan laporan yang lebih cepat dan efisien, sehingga dapat memudahkan pimpinan dalam mengambil keputusan untuk kegiatan bisnis perusahaan.

Beberapa permasalahan yang terjadi pada PT Alimina sebagai berikut:

1. Terlambatnya proses produksi dikarenakan perhitungan bahan-bahan baku masih menggunakan sistem manual yang rumit.

2. Memerlukan waktu yang lama untuk mendapat laporan Harga Pokok Penjualan (HPP) berjalan dari hasil produksi.

3. Adanya kemungkinan dalam kesalahan perhitungan bahan- bahan baku produksi. 
4. Laporan berjalan tidak dapat diproses secara cepat, data yang diperlukan harus terlebih dahulu dikumpulkan dan diperiksa.

Adapun tujuan yang ingin dicapai penulis dalam penulisan ini adalah untuk mengembangkan sebuah sistem pengelolaan produksi sehingga dapat membantu PT. Alumina dalam pengelolaan data secara komputerisasi dan pembuatan laporan-laporan dengan cepat dan efisien.

Adapun manfaat pengembangan yang diusulkan dapat mengatasi permasalahan yang terjadi seperti:

1. Tidak terlambatnya proses produksi dikarenakan perhitungan bahan-bahan baku.

2. Dapat menghasilkan laporan Harga Pokok Penjualan (HPP) berjalan sewaktu produksi berlangsung.

3. Pengendalian bahan baku menjadi efisien karena perhitungan bahan sudah terkomputerisasi, berkurangan selisih antara barang fisik dan stok.

4. Laporan-laporan dihasilkan dengan efisien dan tepat waktu.

\section{TEORITIS}

\subsection{Sistem Informasi}

Adapun definisi teknis dari sistem informasi adalah rangkaian komponen yang saling terintegrasi untuk mengumpulkan atau mendapatkan, memproses, menyimpan, dan pengawasan data dalam organisasi. Sistem informasi meliputi sumber daya manusia (pengguna akhir dan spesialis sistem informasi), hardware (mesin dan media), software (program dan prosedur), data (data dan basis pengetahuan), dan jaringan (media komunikasi dan dukungan jaringan) untuk melakukan aktivitas input, proses, output, storage, dan kontrol yang mentransformasikan data ke dalam informasi. [1].

\subsection{Metodologi Siklus Hidup Pengembangan Sistem (SDLC)}

Siklus hidup pengembangan sistem atau System Development Life Cycle (SDLC) merupakan pendekatan yang dilakukan melalui beberapa tahap untuk menganalisis dan merancang sistem yang telah dikembangkan dengan sangat baik melalui penggunaan siklus kegiatan penganalisis dan pemakaian secara spesifik. Dari definisi di atas, dapat diartikan bahwa siklus hidup pengembangan sistem merupakan rangkaian proses atau tahap dalam menganalisis suatu sistem dalam mencapai suatu tujuan [2]. Tahap utama dari siklus hidup pengembangan sistem seperti terlihat pada gambar berikut ini:

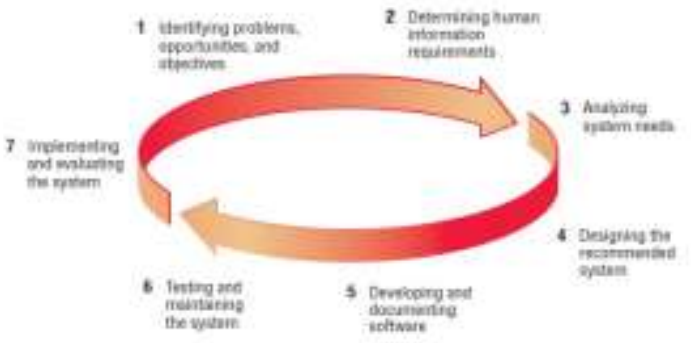

Gambar 1. Siklus Hidup Pengembangan Sistem

1. Mengidentifikasi Masalah, Peluang dan Tujuan

Masalah, peluang dan tujuan yang hendak dicapai diidentifikasi pada tahapan ini. Tahapan ini memungkinkan bisnis untuk mencapai sisi kompetitif sekaligus menyusun standar industri yang dibutuhkan

2. Menentukan Syarat-Syarat Informasi

Tahapan ini membutuhkan analis untuk mendaftarkan syarat informasi untuk setiap pemakai yang akan terlibat. Kegiatan ini dapat dilakukan dengan penentuan sampel, investigasi, wawancara dan observasi perilaku pembuat keputusan di lingkungan kantor dan prototyping.

3. Menganalisis Kebutuhan Sistem

Kebutuhan sistem dianalisis di tahapan ini. Perangkat yang dibutuhkan untuk membantu analis dalam menentukan kebutuhan dapat meliputi diagram aliran data. Pada tahapan ini keputusan terstrukutr dimana kondisi alternatif, tindakan serta aturan tindakan yang ada juga turut dianalisis.

4. Merancang Sistem yang Direkomendasikan

Tahapan ini menuntut analis sistem untuk mulai melakukan desain sistem informasi yang logik. Perangkat yang digunakan dapat meliputi peralatan antarmuka pengguna.

5. Mengembangkan dan Mendokumentasikan Perangkat Lunak

Pada tahapan ini sistem analis bekerja sama dengan pemrogram untuk mulai mengembangkan perangkat lunak. Teknik untuk merancang dan mendokumentasikan perangkat lunak seperti Nassi-Shneiderman charts, dan pseudocode juga turut dilibatkan.

6. Menguji dan Mempertahankan Sistem 
Kegiatan pengujian dilaksanakan pada tahapan ini, pengujian dapat dilakukan dalam beberapa tahapan baik oleh pemrogram sendiri, bersama dengan analis sistem bahkan dapat diujikan mulai dengan menggunakan data contoh hingga data aktual dari sistem yang ada.

7. Mengimplementasikan dan Mengevaluasi Sistem

Tahapan ini merupakan tahapan dimana sistem aalisis melakukan implementasi sistem yang sudah dikembangkan. Kegiatan ini melibatkan pelatihan dan konversi dari sistem lama ke sistem baru. [2].

\subsection{Produksi}

Produksi dapat diartika sebagai kegiatan pengarahan dan pengendalian untuk mengolah sumber daya untuk menghasilkan barang atau jasa tertentu. Sistem produksi selain terdapat pada industri manufaktur, juga meliputi industri jasa, perbankan, asuransi, retail, rumah sakit dan lainnya. Sistem produksi dan operasi dalam industri jasa menggunakan bauran yang berbeda dari masukan yang di pergunakan dalam industri manufaktur [3].

Sistem produksi yang sering digunakan dapat dibedakan menjadi 3 macam yaitu:

1. Proses produksi yang kontiniu (continuous process) dimana peralatan produksi yang dikelola dengan memperhatikan routing untuk menghasilkan produk, serta aliran bahan dalam proses terstandarisasi.

2. Proses produksi terputus (intermitten process) dimana kegiatan produksi tidak standar dan berbeda untuk produk yang dikerjakan, sehingga peralatan produksi yang dikelola dapat lebih luwes (flexible) agar dapat dipergunakan untuk menghasilkan produk dan berbagai ukuran.

3. Proses produksi yang bersifat proyek dengan kegiatan produksi yang dapat dilakukan tempat dan waktu yang berbeda. Kondisi ini menyebabkan peralatan produksi yang digunakan berada di lokasi proyek. [3].

\section{HASIL DAN PEMBAHASAN}

Metodologi pengembangan sistem yang akan digunakan adalah metodologi SDLC (System Development Life Cycle) yang merupakan suatu pendekatan berupa tahapan dalam menganalisis dan desain yang digunakan sebagai pedoman untuk mengembangkan sistem. Adapun tahapan-tahapan dari metode SDLC yang digunakan penulis sampai tahapan ke lima yaitu:

1. Mengidentifikasi Masalah, Peluang dan Tujuan

Pada tahapan ini, penulis melakukan analisis permasalahan pada sistem berjalan. Berdasarkan hal tersebut, penulis mencari solusi untuk mengatasi masalah yang sedang dihadapi PT. Alumina dengan mengusulkan rancangan sistem informasi produksi. Rancangan tersebut bertujuan untuk membantu proses pengelolaan laporan produksi perusahaan secara cepat dan tepat. Mengidentifikasi masalah penulis berencana menggunakan diagram Fishbone.

2. Menentukan Syarat-Syarat Informasi

Pada tahapan ini, penulis akan mengumpulkan berbagai fakta dan informasi yang dibutuhan untuk melakukan perancangan sistem. Dalam pengumpulan informasi ini, penulis akan menggunakan beberapa teknik pengumpulan data yakni:

3. Menganalisis Kebutuhan Sistem

Pada tahapan, kebutuhan sistem dianalisis. Kebutuhan fungsional akan dimodelkan dengan menggunakan use case dan perangkat non-fungsional menggunakan diagram PIECES. Aliran proses akan dimodelkan mengunakan Diagram Aliran Data

4. Merancang Sistem yang Direkomendasikan

Berdasarkan diagram aliran data, kegiatan dilanjutkan dengan merancang output, form-form, dan user interface yang diperlukan sistem usulan. Perancangan form-form tersebut akan dirancang menggunakan Microsoft Visual Basic 2012, database dengan menggunakan Microsoft SQL Server 2012 dan dilengkapi dengan Crystal Report 13.0.5 dalam perancangan laporan.

5. Mengembangkan dan Mendokumentasikan Perangkat Lunak

Untuk mengembangkan sistem produksi penulis menggunakan aplikasi Microsoft Visual Basic 2012, Microsoft SQL Server 2012, dan Crystal Report 13.0.5 (pembuatan laporan) yang dapat mendukung dalam melakukan pengembangan ini.

Untuk memudahkan pengguna dalam penggunaan sistem informasi produksi, penulis membuat urutan penggunaan sistem inputasi seperti yang terlihat pada gambar berikut. 


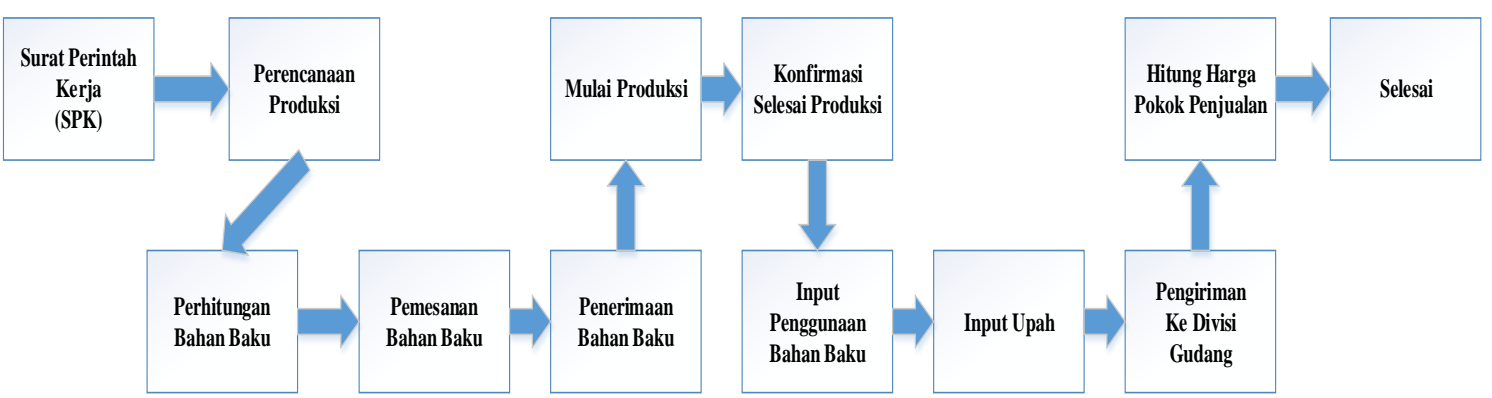

Gambar 2. Siklus Status Produksi pada Sistem Informasi Produksi

Berikut ini adalah tampilan relasi antar tabel pada sistem informasi produksi PT. Alumina :

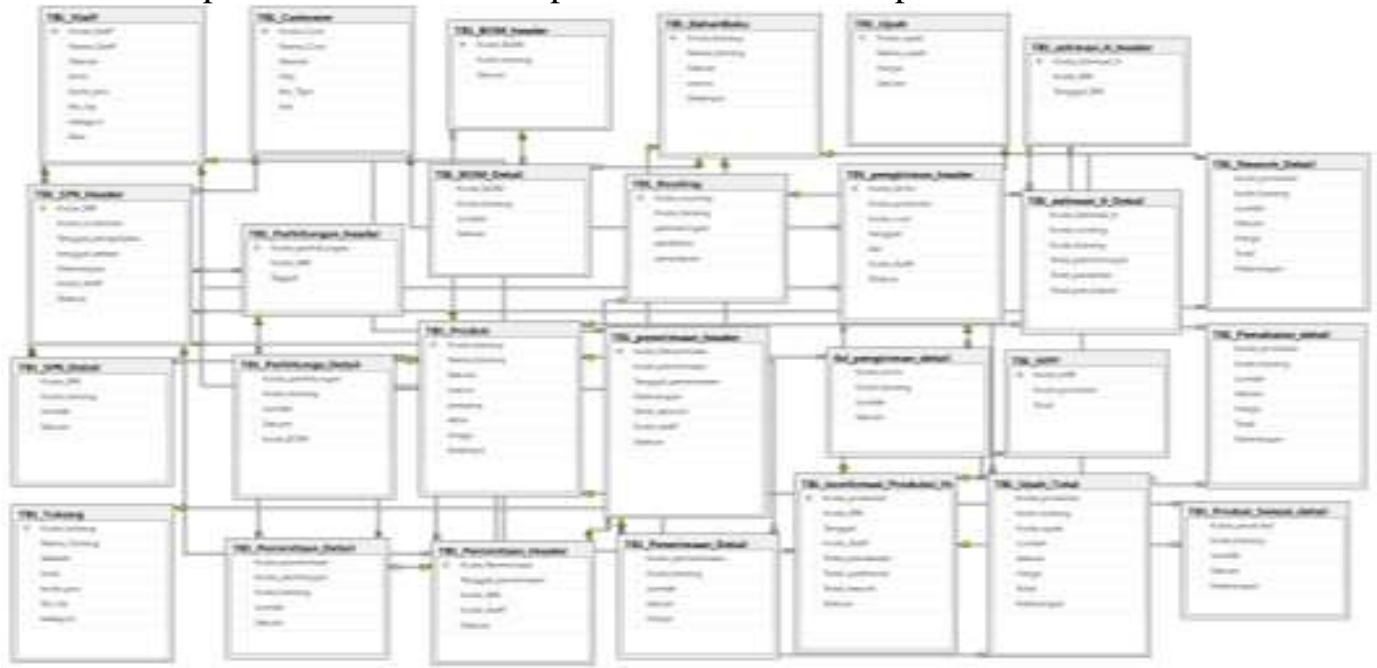

Gambar 3 Tampilan Relasi Tabel

Terdapat 5 menu utama pada halaman utama yakni menu master, menu produksi, menu laporan, menu staff dan menu Data flow.

1. Menu master

Berisi master-master yang digunakan pada saat transaksi. Penjelasan masing-masing sub-menu pada menu master yaitu:

a. Barang

Form barang berfungsi untuk menambah data dan mengubah data barang bahan baku dan produk. Pengguna cukup menekan tombol radio button kategori saat akan mengisi data barang baru lalu program secara otomatis akan menampilkan kode barang baru. Jika ingin mengubah data barang, pengguna cukup menekan tombol cari yang berada di sebelah textbox kode bahan baku untuk menampilkan data yang akan diubah ke form barang (tombol BK untuk bahan baku dan tombol BP untuk Produk).

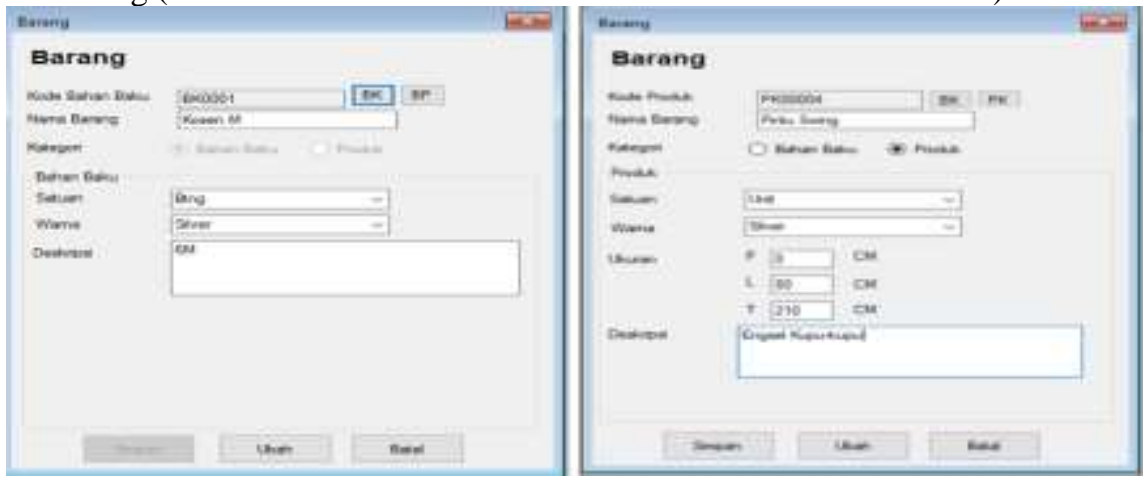

Gambar 4. Tampilan form masukan item sebagai Bahan Baku dan Produk

b. Tukang

Form tukang berfungsi untuk menambah dan mengubah data tukang yang akan mengerjakan proses produksi ini. Kode tukang akan muncul otomatis saat form tukang dibuka. Jika ingin mengubah data tukang, pengguna cukup menekan tombol cari yang berada di sebelah textbox kode tukang untuk dapat memilih data tukang yang akan diubah.

c. Upah 
Form upah berfungsi untuk menambah dan mengubah data upah. Kode upah akan muncul otomatis saat form upah dibuka. Jika ingin mengubah data upah, pengguna cukup menekan tombol cari yang berada di sebelah textbox kode upah untuk dapat memilih data upah yang akan diubah.

d. Bill of Material (BOM) dan Routing

Berisi data-data bahan baku yang dibutuhkan untuk membuat suatu produk. Saat membuka form BOM, kode BOM akan otomatis muncul kemudian pengguna harus menekan tombol cari yang berada di sebelah textbox kode barang untuk memilih data produk lalu memilih bahan baku apa saja yang akan dipakai untuk membuat suatu produk.

Form ini berfungsi untuk menambah atau mengubah data-data waktu (menit) perhitungan pembuatan dari suatu produk. Saat form ini dibuka kode routing akan otomatis muncul dan pengguna cukup memilih produk yang akan di-input datanya dengan menekan tombol cari yang berada di sebelah textbox kode barang.
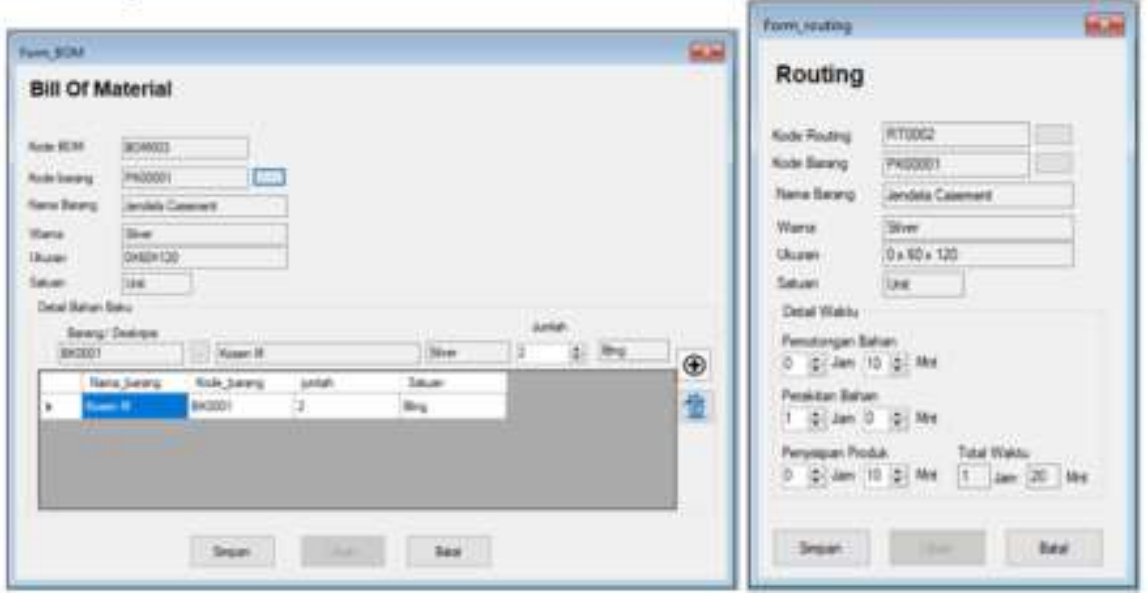

Gambar 5. Tampilan form input data Bill of Material (BOM) dan Routing

2. Menu Produksi

Berisi transaksi-transaksi yang akan dilaksanakan sebelum dan sesudah kegiatan produksi dilakukan. Penjelasan masing-masing sub-menu pada menu produksi yaitu:

a. $\quad$ Surat Perintah Kerja (SPK)

Transaksi ini dilakukan pada saat pesanan dari pelanggan akan diteruskan ke bagian produksi, dan secara otomatis program akan memunculkan permintaan dan perhitungan bahan baku. Pengguna juga dapat melihat estimasi lama produksi dari form ini serta data flow atau melihat segala aktivitas produksi dari penerimaan SPK, pemesanan bahan baku, penerimaan bahan baku, proses produksi, dan pengiriman ke divisi gudang.

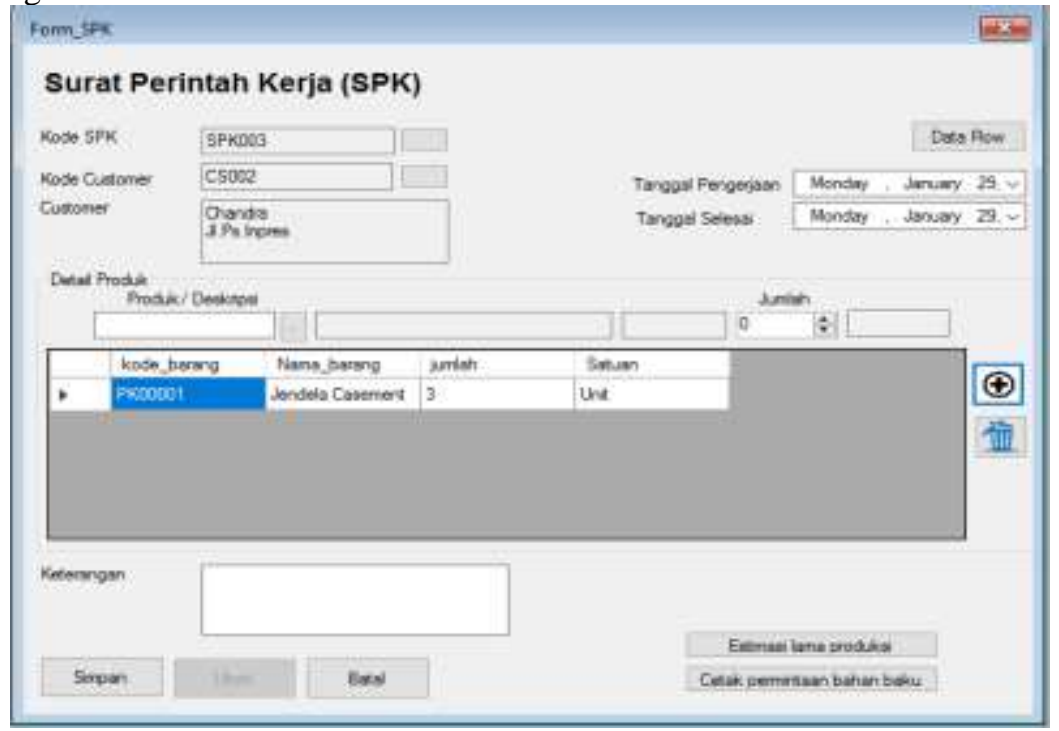

Gambar 6 Tampilan form input data Surat Perintah Kerja (SPK)

b. Penerimaan Bahan Baku

Transaksi ini dilakukan saat bahan baku sudah diterima dari divisi gudang sesuai permintaan bahan baku dan berdasarkan SPK yang sudah di-input. 


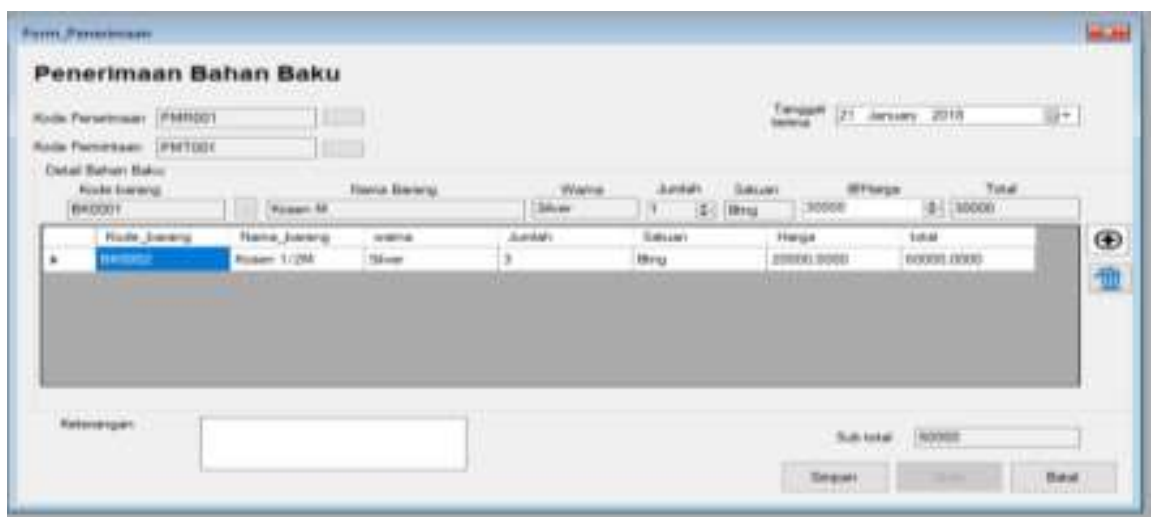

Gambar 7. Tampilan form input data Penerimaan Bahan Baku

c. Konfirmasi Produksi

Transaksi ini dilakukan saat produk sudah selesai. Kemudian pengguna harus mengisi data produk selesai, pemakaian bahan baku, upah dan rework pada form ini.

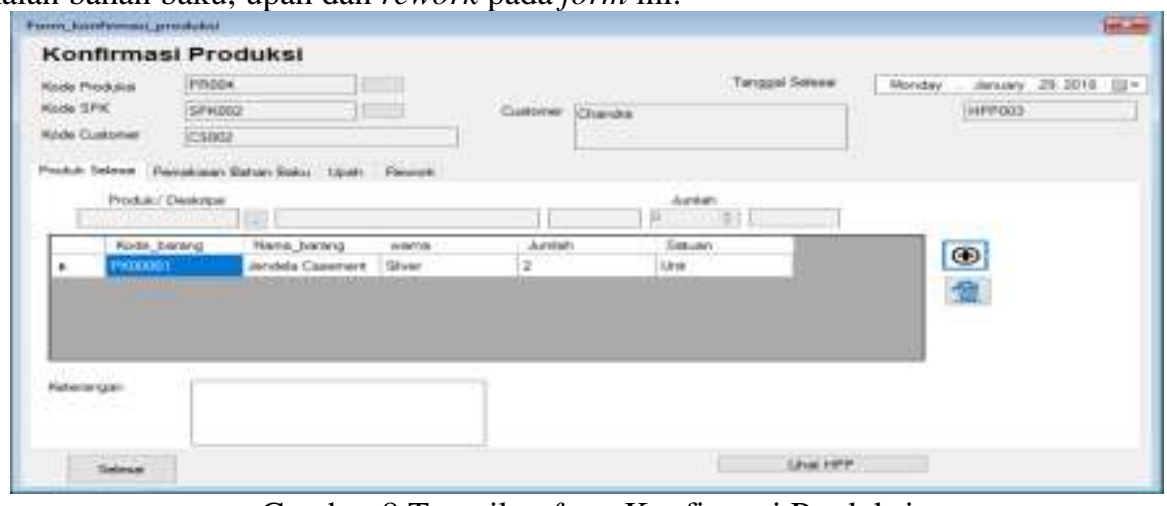

Gambar 8 Tampilan form Konfirmasi Produksi

d. Pengiriman

Transaksi ini dilakukan saat divisi produksi akan mengirimkan produk yang telah selesai untuk disimpan di gudang.

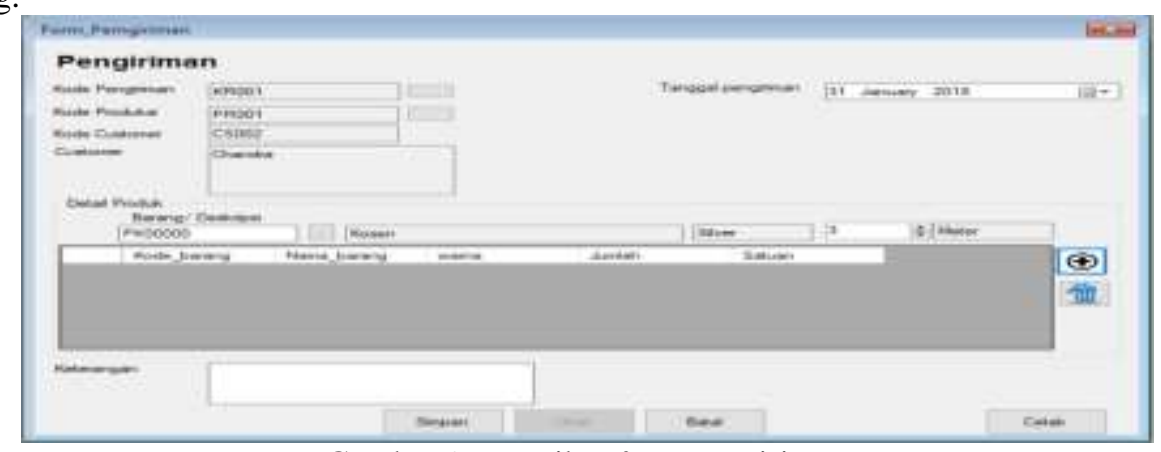

Gambar 9 Tampilan form Pengiriman

3. Menu Laporan

Laporan merupakan hasil pengolahan data yang dilakukan oleh sistem informasi. Penjelasan dari sub-menu pada menu laporan yaitu :

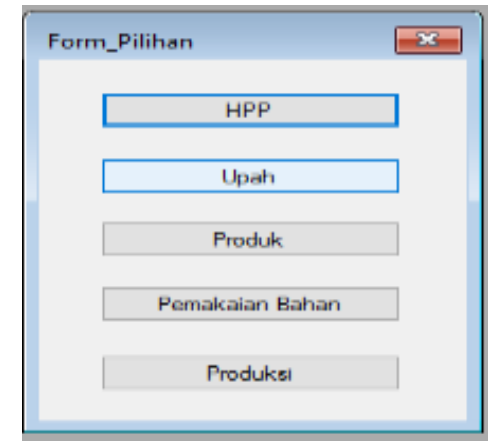

Gambar 10. Tampilan form sub-menu laporan 
a. Harga Pokok Penjualan (HPP)

Berfungsi untuk menampilan harga pokok penjualan (HPP) dalam status selesai produksi dengan keterangan no, tanggal, kode HPP, kode produksi, kode SPK, kode customer, nama customer dan total HPP.

b. Upah

Berfungsi untuk menampilkan total upah dalam satu produksi berdasarkan SPK dalam status selesai produksi dengan keterangan grup kode SPK, no, tanggal, kode produksi, kode tukang, nama tukang, tanggal dan total upah.

c. Produk

Berfungsi untuk menampilan produk yang sudah selesai dalam satu produksi yang status selesai produksi dengan keterangan grup kode produksi, kode SPK, nama customer, no, kode barang, nama_barang, warna, jumlah dan satuan.

d. Pemakaian Bahan

Berfungsi untuk menampilan pemakaian bahan baku dalam satu produksi berdasarkan SPK dengan status selesai produksi dengan keterangan grup kode SPK, kode produksi, tanggal, no, kode barang, nama barang, warna, jumlah, harga, total dan sub total seluruhnya.

e. Produksi

Berfungsi untuk menampilan seluruh produksi berdasarkan SPK dalam status selesai produksi dengan keterangan No, kode produksi, kode SPK, kode customer, nama customer, no telepon, tanggal pengerjaan, tanggal selesai produksi dan status.

4. Menu Staff

Berisi data-data staff atau admin. Ketika pemilik membuka form input staff maka pengguna dapat memilih kategori yang mau dimasukan dan kode untuk staff akan muncul secara otomatis.

5. Menu Data Flow

Menu ini berfungsi untuk melihat segala aktivitas produksi dari penerimaan SPK, pemesanan bahan baku, penerimaan bahan baku, proses produksi, dan pengiriman ke divisi gudang.

\section{KESIMPULAN}

Dari hasil penelitian yang telah dilakukan oleh penulis pada PT Alumina maka kesimpulan yang didapat adalah sebagai berikut:

1. Dengan adanya sistem informasi ini dapat membantu perusahaan dalam perhitungan bahan baku yang lebih cepat dan akurat, dan menguragi kesalahan perhitungan bahan baku.

2. Dengan adanya sistem informasi ini dapat membantu perusahaan untuk memperoleh harga pokok penjualan dari hasil produksi dengan cepat.

3. Dengan adanya sistem informasi ini dapat membantu perusahaan menganalisis waktu produksi dengan adanya routing.

4. Dengan adanya sistem informasi ini dapat membantu pengendalian bahan baku yang di terima oleh divisi produksi.

5. Dengan adanya sistem informasi ini dapat membantu perusahaan untuk mengetahui pelaksanaan status proses produksi baik yang sudah selesai dilaksanakan maupun yang masih direncanakan/belum selesai.

6. Dengan adanya sistem informasi ini dapat membantu perusahaan dapat memperoleh laporan lebih cepat dan akurat dan dapat dilihat langsung tanpa harus dicetak.

\section{REFERENCES}

[1] Jogiyanto, Analisis dan Desain Sistem Informasi, Edisi IV, Yogyakarta: Andi Offset, 2010.

[2] K.E. Kendall, dan J.E. Kendall, System Analysis and Design, Edisi 9, USA: Pearson Education, 2014.

[3] P.M. Pardede, Manajemen Operasi dan Produksi (Teori, Model, dan Kebijakan), Yogyakarta: ANDI, 2005. 